\title{
SISTEM INFORMASI GEOGRAFIS \\ METADATA SUMBER DAYA MINERAL DAN ENERGI INDONESIA BERBASIS WEB
}

\author{
Oleh: \\ Retno Rahmawati \\ Pusat Sumber Daya Geologi \\ JI. Soekarno Hatta No. 444, Bandung.
}

\begin{abstract}
SARI
Dalam meningkatkan pengelolaan dan pelayanan serta pemanfaatan data dan informasi potensi sumber daya mineral dan energi, Pusat Sumber Daya Geologi (PSDG) merupakan salah satu instansi pemerintah yang bertanggung jawab dalam mengelola data tersebut. Salah satu upayanya adalah dengan melakukan pemutakhiran metadata sumber daya mineral dan energi. Metadata diperlukan untuk mengindentifikasi dan memberikan informasi dari suatu data, metadata sering disebut data tentang data atau informasi tentang informasi. Dengan semakin banyaknya data dan informasi yang tersedia maka diperlukan suatu aplikasi Sistem Informasi Geografis (SIG) untuk mengelola metadata sumber daya mineral dan energi ini. Selain itu dengan meluasnya penggunaan internet sebagai media pertukaran informasi, maka aplikasi SIG ini dibuat berbasis Web. Tulisan ini menggambarkan langkah langkah dalam membuat aplikasi SIG yang akan mengelola metadata sumber daya mineral dan energi di Lembar Solok sebagai contoh di Indonesia.
\end{abstract}

Kata kunci : metadata, sistem informasi geografis, Pusat Sumber Daya Geologi.

\section{ABSTRACT}

To improve management and service for utilization of data and information of mineral and energy resources in Indonesia, Center for Geological Resources (CGR) is one of the Government Agency responsibles to manage the data. One of the effort is up-dating the metadata of mineral and energy resources. Metadata is needed to identify and provide the information from the data. Metadata is often called data about data or information about information. Since Indonesia has a lot of data of mineral and energy resources, it is necessary to have Geographic Information System (GIS) to manage the metadata. In addition, due to the widespread use of the internet as medium of exchange of information, the application is made in Web based. This paper describes the steps of making the application of GIS to manage the metadata of mineral and energy resources in Solok area as an example in Indonesia.

Key words: metadata, Geographic Information System, Centerfor Geological Resources.

\section{PENDAHULUAN}

Indonesia merupakan salah satu negara yang kaya akan sumber daya mineral dan energi, seperti mineral logam, non logam, batubara, bitumen padat, gambut dan panas bumi. Sebagai salah satu negara yang memiliki potensi sumber daya mineral dan energi yang cukup potensial, Indonesia dapat menjadi negara yang maju dalam melakukan pengelolaan pertambangan mineral dan energi. Hampir semua potensi mineral dan energi tersebar merata di seluruh Indonesia dan data sumber daya tersebut dikelola oleh Pusat Sumber Daya Geologi (PSDG), Badan Geologi, Kementerian ESDM sebagai salah satu instansi pemerintah yang bertanggung jawab dalam mengelola data dan informasi tersebut. PSDG telah melakukan pemutakhiran metadata sumber daya mineral dan energi dalam melaksanakan misinya yaitu meningkatkan pengelolaan dan pelayanan serta pemanfaatan data dan informasi potensi sumber daya mineral dan energi.

Metadata adalah informasi terstruktur yang menggambarkan, menjelaskan, menempatkan atau membuatnya lebih mudah untuk menggunakan dan mengelola sumber informasi, metadata sering disebut juga dengan data tentang data atau informasi tentang informasi (National Information Standards Organization, 2004). Dalam pemutakhiran metadata saat ini data yang dikelola adalah data sumber daya mineral dan energi di Indonesia yang terdiri dari mineral logam, mineral non logam, batubara, bitumen padat, gambut dan panas bumi yang telah diinventarisasi oleh PSDG.

Pemutakhiran metadata diperlukan dalam mengelola data sumber daya mineral dan energi, 


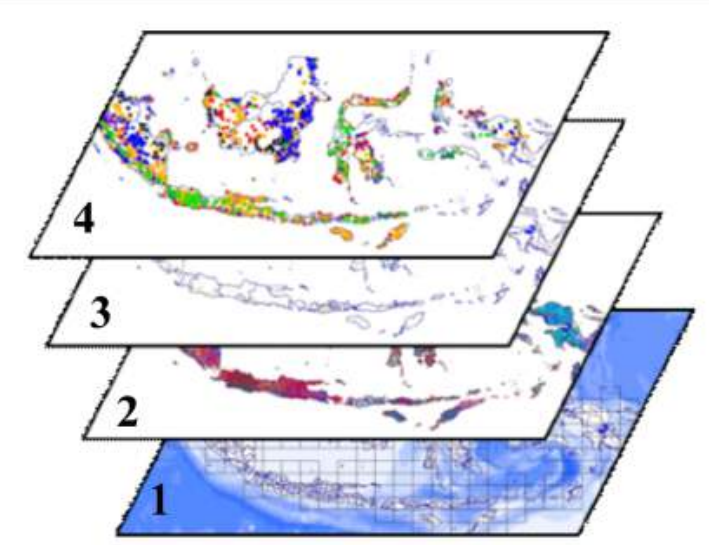

Keterangan :

1. Layer lembar peta rupa bumi Indonesia

2. Layer batas kabupaten, sungai, jalan

3. Layer data geologi disederhanakan/formasi batuan pembawa logam /formasi batuan pembawa batubara

4. Layer data sumber daya mineral dan energi

Gambar 1. Konsep layer SIG

karena metadata mempunyai beberapa fungsi, diantaranya untuk mengelola data dan informasi sehingga dapat mudah ditemukan dengan menggunakan kriteria yang relevan. Metadata dapat juga mengindentifikasi data dan informasi, mengelompokkan data dan informasi yang serupa, serta memberikan informasi dari suatu data, seperti sumber data tersebut (Wikipedia, 2011a). Fungsi metadata tersebut menyerupai fungsi katalog, maka dengan tersusunnya metadata sumber daya mineral dan energi dapat menjadi katalog data sumber daya geologi.

Dalam melakukan pemutakhiran metadata, data yang dikelola adalah data potensi sumber daya mineral dan energi dan beragam data pendukungnya. Dengan semakin banyaknya data yang dikelola maka diperlukan suatu aplikasi yang dapat mengelola metadata sumber daya mineral dan energi ini. Dalam melakukan pemutakhiran metadata ini, aplikasi yang tepat digunakan adalah Sistem Informasi Geografis (SIG). SIG merupakan suatu sistem informasi yang mengelola data spasial atau sistem komputer yang memiliki kemampuan untuk membangun, menyimpan, mengelola, dan menampilkan informasi bereferensi geografi (Riyanto, 2009)

\section{METODE}

Metode yang digunakan dalam membangun aplikasi metadata sumber daya mineral dan energi ini terdiri dari :

\section{Inventarisasi Data}

Inventarisasi data adalah pengumpulan data yang akan dikelola dalam aplikasi metadata yaitu data dengan status terbaru untuk sumber daya mineral dan energi. Indonesia memiliki beragam komoditi mineral dan energi, yaitu 23 komoditi mineral logam, 53 komoditi mineral non logam, batubara, bitumen padat, gambut dan panas bumi. Selain data potensi tersebut, terdapat juga data pendukungnya, diantaranya peta geologi disederhanakan, formasi batuan pembawa logam dan formasi batuan pembawa batubara. Metadata akan disajikan dengan mengacu kepada peta rupa bumi keluaran Badan Koordinasi Survei dan Pemetaan Nasional (BAKOSURTANAL) dengan skala $1: 250.000$ kecuali untuk pulau Jawa yaitu dengan skala 1 : 100.000. Jumlah keseluruhan lembar peta tersebut adalah 330 lembar peta. Terlampir tabel komoditi sumber daya mineral dan energi (Lampiran A) dan lembar peta Indonesia (Lampiran B).

Dari data yang telah terinventarisasi tersebut, maka dapat ditentukan lembar (layer) yang akan dimasukkan ke dalam aplikasi metadata sumber daya mineral dan energi, seperti terlihat pada Gambar 1.

\section{Menyusun Skema Metadata}

Hingga saat ini terdapat beragam skema metadata yang masih terus dikembangkan sebagai standar metadata untuk seluruh disiplin ilmu, diantaranya ilmu sosial, pengarsipan, perpustakaan, dll. (Wikipedia, 2011b). Dalam 
Tabel 1.

Skema metadata sumber daya mineral dan energi

\begin{tabular}{|c|c|c|}
\hline NO & UNSUR & KETERANGAN/DESKRIPSI \\
\hline 1 & pemilik_data_sitasi & Nama pemilik data \\
\hline 2 & judul_sitasi & Judul lembar peta \\
\hline 3 & bentuk_tampilan_data_sitasi & Bentuk tampilan metadata \\
\hline 4 & tempat_sitasi & Tempat pemilik data \\
\hline 5 & penerbit_sitasi & Penerbit data \\
\hline 6 & pemilik_data_larger_work_identifikasi & Nama pemilik data \\
\hline 7 & judul_larger_work_identifikasi & Judul lembar peta \\
\hline 8 & bentuk_tampilan_data_larger_work_identifikasi & Bentuk tampilan metadata \\
\hline 9 & abstrak & abstrak lembar peta \\
\hline 10 & tujuan & tujuan pembuatan metadata \\
\hline 11 & status_kemajuan & status kemajuan pembuatan metadata \\
\hline 12 & bujur_barat & koordinat bujur barat lembar peta \\
\hline 13 & bujur_timur & koordinat bujur timur lembar peta \\
\hline 14 & lintang_utara & koordinat lintang utara lembar peta \\
\hline 15 & lintang_selatan & koordinat lintang selatan lembar peta \\
\hline 16 & kata_kunci_tema & nama komoditi sumber daya mineral dan energi \\
\hline 17 & tempat_thes & nama daerah lembar peta \\
\hline 18 & personil_titik_kontak & nama kontak person sumber data \\
\hline 19 & organisasi_utama_titik_kontak & nama organisasi kontak person sumber data \\
\hline 20 & jabatan_titik_kontak & nama jabatan kontak person sumber data \\
\hline 21 & alamat_titik_kontak & alamat pemilik data \\
\hline 22 & kota_titik_kontak & kota pemilik data \\
\hline 23 & propinsi_titik_kontak & propinsi alamat pemilik data \\
\hline 24 & kode_pos_titik_kontak & kodepos alamat pemilik data \\
\hline 25 & negara_titik_kontak & negara alamat pemilik data \\
\hline 26 & telepon_titik_kontak & telepon pemilik data \\
\hline 27 & faksimili_titik_kontak & faksimili pemilik data \\
\hline 28 & email_titik_kontak & website pemilik data \\
\hline 29 & jam_kontak_titik_kontak & jam kerja pemilik data \\
\hline 30 & tgl_metadata & tanggal disusunnya metadata \\
\hline 31 & nama_standars & nama standar metadaya \\
\hline 32 & versi & versi penyusun metadata \\
\hline 33 & Biaya & harga produk peta pemilik data \\
\hline 34 & Instruksi Pemesanan & cara pemesanan peta \\
\hline
\end{tabular}

pembuatan metadata sumber daya mineral dan energi ini, skema metadata dan unsur-unsur yang digunakan mengacu pada standar Digital Geospatial Metadata FGDC-STD-001-1998.

Pada standar metadata ini terdapat banyak unsur yang dimasukkan ke dalam aplikasi metadata, dan dalam metadata sumber daya mineral dan energi, unsur-unsur tersebut telah disederhanakan tanpa mengurangi nilai informasi yang diperlukan. Unsur-unsur yang digunakan dalam membuat skema metadata sumber daya mineral dan energi dapat dilihat Tabel 1.

\section{Analisa Sistem}

Dalam analisa sistem terdapat dua hal yang disiapkan, yaitu perancangan basis data dan navigasi WebGIS, hal ini dilakukan agar aplikasi metadata ini dapat berfungsi optimal dan sesuai dengan kebutuhan pengguna.

\section{Perancangan Basis Data}

Setelah struktur metadata ditentukan, langkah selanjutnya adalah merancang basis data sesuai dengan struktur metadata. Dalam merancang metadata hal-hal yang perlu dilakukan adalah membuat tabel-tabel data yang akan dimasukkan dalam aplikasi metadata dan melakukan normalisasi data. Normalisasi data adalah proses yang fleksibel untuk menggantikan hubungan yang ditentukan oleh koleksi yang berurutan dimana hubungan tersebut mempuyai suatu struktur yang lebih 


\begin{tabular}{|c|c|c|c|c|c|c|c|c|}
\hline \multicolumn{3}{|c|}{ Tabel Komoditi } & & & & \multicolumn{3}{|c|}{ Tabel Sitasi } \\
\hline Field Name & Data Type & Field Size & & & & Field Name & Data Type & Field Size \\
\hline id_komoditi & text & 10 & & & & id_sitasi & text & 10 \\
\hline nama_komoditi & text & 30 & & & & pemilik_sitasi & text & 50 \\
\hline kode & text & 10 & \multirow{2}{*}{\multicolumn{3}{|c|}{ Tabel Metadata }} & bentuk & text & 50 \\
\hline kelompok & text & 30 & & & & & tont & 50 \\
\hline lokasi & text & 50 & Field Name & Data Type & Field Size & tempat & text & 50 \\
\hline kecamatan & text & 50 & ID_metadata & text & 10 & penerbit & text & 50 \\
\hline kabupaten & text & 30 & id_sitasi & text & 10 & personil & text & 50 \\
\hline provinsi & text & 30 & id_Ip & text & 10 & jabatan & text & 50 \\
\hline tkt_penyelidikan & text & 30 & judul_metadata & text & 100 & alamat & text & 50 \\
\hline bijih_hipotetik & number & decimal & abstrak_metadata & text & 255 & kota & text & 50 \\
\hline logam_hipotetik & number & decimal & status & text & 25 & provinsi & text & 50 \\
\hline bijih_tereka & number & decimal & bujur_barat & number & decimal & kode_pos & text & 10 \\
\hline logam_tereka & number & decimal & bujur_timur & number & decimal & negara & text & 50 \\
\hline bijih_tertunjuk & number & decimal & lintang_utara & number & decimal & telepon & text & 25 \\
\hline logam_tertunjuk & number & decimal & lintang_selatan & number & decimal & faksimile & text & 25 \\
\hline bijih_terukur & number & decimal & id_komoditi & text & 10 & Taksimile & text & 25 \\
\hline logam_terukur & number & decimal & tanggal_metadata & date & & website & text & 50 \\
\hline bijih_terkira & number & decimal & nama standar & text & 255 & jam & text & 25 \\
\hline logam_terkira & number & decimal & Halind_stanual & jext & 203 & versi & text & 50 \\
\hline bijih_terbukti & number & decimal & & & & biaya & text & 255 \\
\hline logam_terbukti & number & decimal & & & & instruksi & text & 255 \\
\hline keterangan & text & 255 & & & & \multicolumn{3}{|c|}{ Tabel Lembar Peta } \\
\hline sumber_data & text & 255 & & & & \begin{tabular}{|l} 
Field Name \\
\end{tabular} & Data Type & Field Size \\
\hline $\begin{array}{l}\text { bujur } \\
\text { lintang }\end{array}$ & number & decimal & & & & id_lp & text & 10 \\
\hline & & & & & & no_lembar_peta & text & 10 \\
\hline & & & & & & nama_lembar_pe & \begin{tabular}{l|l} 
ta & text \\
\end{tabular} & 50 \\
\hline
\end{tabular}

Gambar 2. Desain normalisasi tabel-tabel metadata sumber daya mineral dan energi

reguler dan sederhana. Proses normalisasi merupakan proses pengelompokkan data elemen menjadi tabel-tabel yang menunjukkan entity dan relasinya (Kristanto, 1999). Tabel-tabel yang akan digunakan pada aplikasi metadata serta hasil proses normalisasi tabel-tabel yang digunakan pada aplikasi metadata ini dapat dilihat dalam Gambar 2.

Setelah proses normalisasi, selanjutnya adalah pembuatan basis data dengan menggunakan geodatabase yaitu basis data relasional yang memuat informasi geografis. Geodatabase terdiri atas tabel (data non spasial) dan feature classes (data spasial) yaitu kumpulan data yang memiliki bentuk geometri dan atribut yang sama, data ini dapat berupa single feature yang dapat disusun dalam suatu feature datasets. Semua data dalam feature ini menggunakan sistem koordinat yang sama, dan dalam hal ini digunakan sistem koordinat derajat desimal dengan proyeksi WGS 84 (Irwan, 2011).

\section{Desain Navigasi WebGIS}

Perancangan desain navigasi WebGIS ini dilakukan untuk memberikan gambaran awal secara menyeluruh tentang akses halaman WebGIS yang dapat dilakukan oleh pengguna. Desain navigasi untuk WebGIS ini dapat dilihat pada gambar 3.

Aplikasi WebGIS metadata ini dirancang untuk penggunaan yang bersifat umum, maka tidak diperlukan fasilitas login. Semua pengguna dapat menggunakan seluruh fitur yang tersedia pada website ini.

\section{Pembuatan Sistem Informasi Geografis}

Pembuatan Sistem Informasi Geografis ini dilakukan untuk membuat peta metadata sumber daya mineral dan energi yang merupakan keluran (output) dari aplikasi metadata berbasis web ini. Peta-peta metadata tersebut dibuat dengan menggunakan perangkat lunak ArcGIS 9.2 berbasis Windows yang diproduksi oleh ESRI. Perangkat lunak ini dapat mengelola data yang memiliki referensi ruang kebumian, sehingga dapat membuat, mengedit dan menganalisa peta dan informasi geografis (Wikipedia, 2011c) (Gambar 4). 


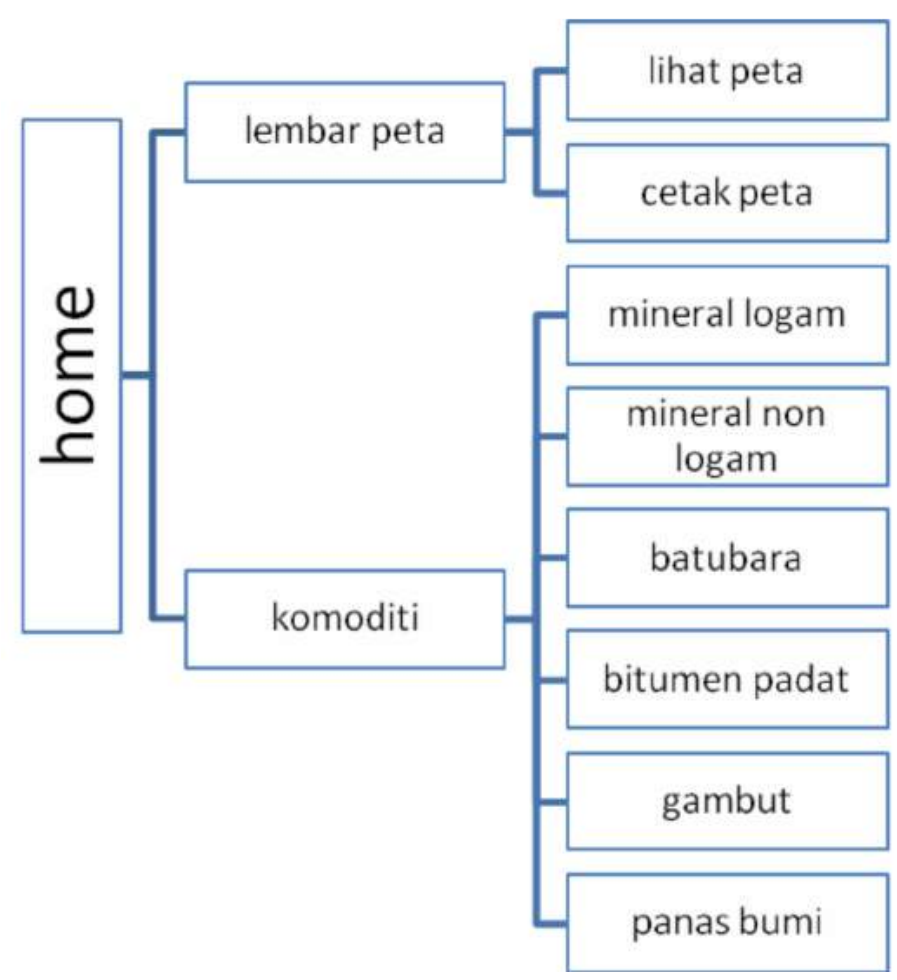

Gambar 3. Desain navigasi aplikasi WebGIS

Dalam SIG ini, layer yang digunakan sesuai dengan data yang telah dikumpulkan, yaitu layer lembar peta rupa bumi Indonesia, layer peta dasar yaitu batas kabupaten, sungai, jalan dan kota di Indonesia, layer data dasar peta geologi yaitu peta geologi disederhanakan, formasi batuan pembawa logam dan formasi batuan pembawa batubara dan layer komoditi sumber daya mineral logam, non logam, batubara, gambut, bitumen padat dan panas bumi. Setelah seluruh layer metadata tersebut selesai dikumpulkan, kemudian diubah atau dikonversi menjadi file JPEG yang akan menjadi keluaran (output) dari aplikasi WebGIS metadata sumber daya mineral dan energi.

Untuk memudahkan pembuatan layer metadata sumber daya mineral dan energi ini pada ArcGIS 9.2 terdapat fasilitas ArcMapBook, yaitu satu fasilitas yang digunakan untuk membuat multi layout atau map series secara otomatis. Sehingga dalam pembuatan peta metadata sumber daya mineral dan energi berdasarkan lembar peta rupa bumi Indonesia yang berjumlah 330 lembar tersebut akan lebih mudah dan tidak memerlukan proses yang lama (Gambar 5).

\section{Membuat aplikasi WebGIS metadata sumber daya mineral dan energi}

Aplikasi WebGIS metadata dibuat agar aplikasi ini dapat diakses oleh pengguna dengan jangkauan yang lebih luas menggunakan fasilitas internet. Aplikasi WebGIS ini dibangun dengan menggunakan perangkat lunak open source Geoserver versi 2.1.3a yang digunakan untuk pengembangan aplikasi internet dalam pengolahan data spasial. Geoserver ditulis dalam bahasa Java dan merupakan implementasi referensi dari standar Open Geospatial Consortium (OGC) Web Feature Service (WFS) dan Web Coverage Service (WCS) (Garnett, 2011) (lihat Gambar 6). 


\section{MAKALAH ILMIAH}

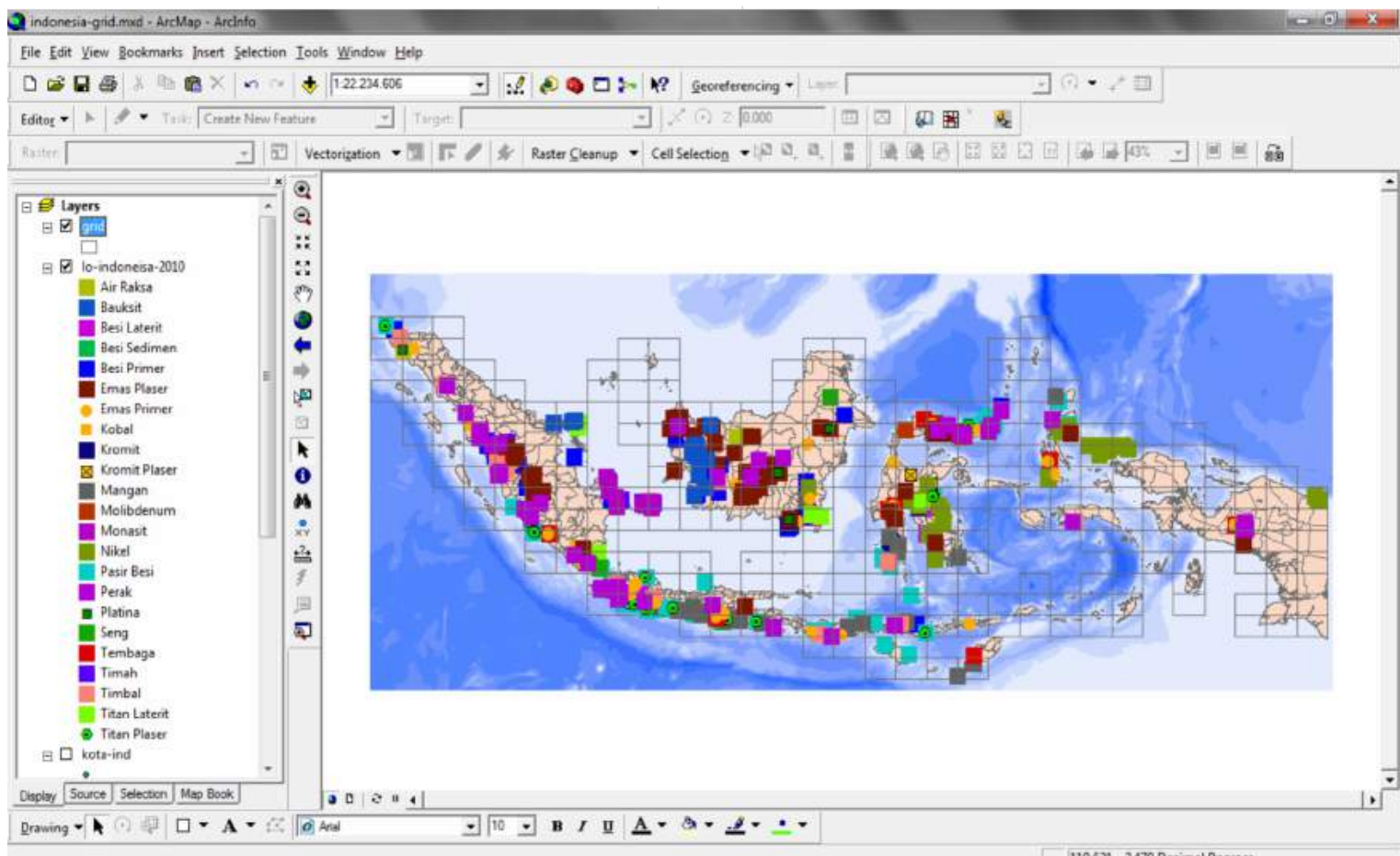

Gambar 4. Sistem Informasi Geografis metadata dengan menggunakan AcrGIS 9.2

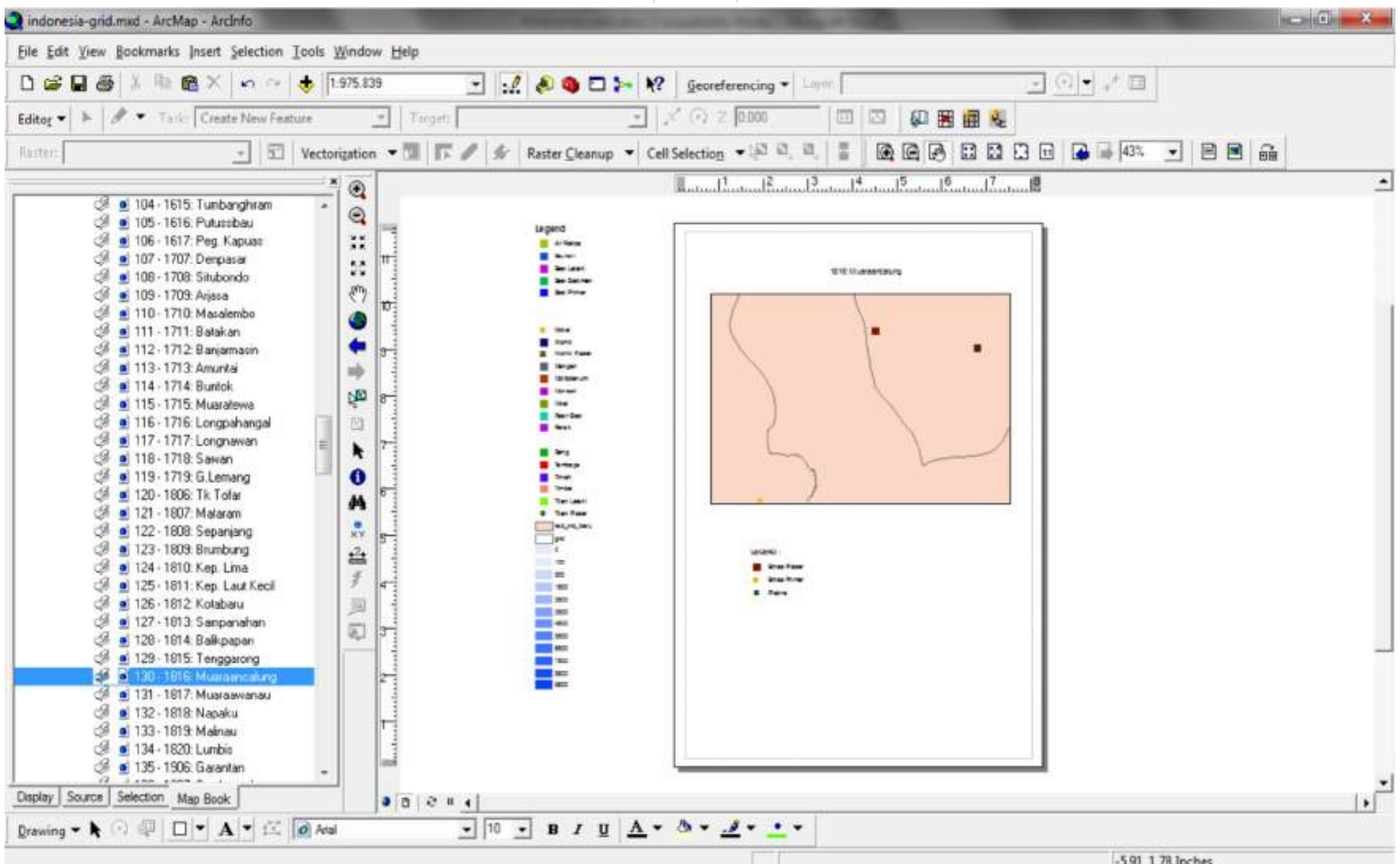

Gambar 5. Sistem Informasi Geografis metadata dengan fasilitas ArcMapBook 


\section{MAKALAH ILMIAH}

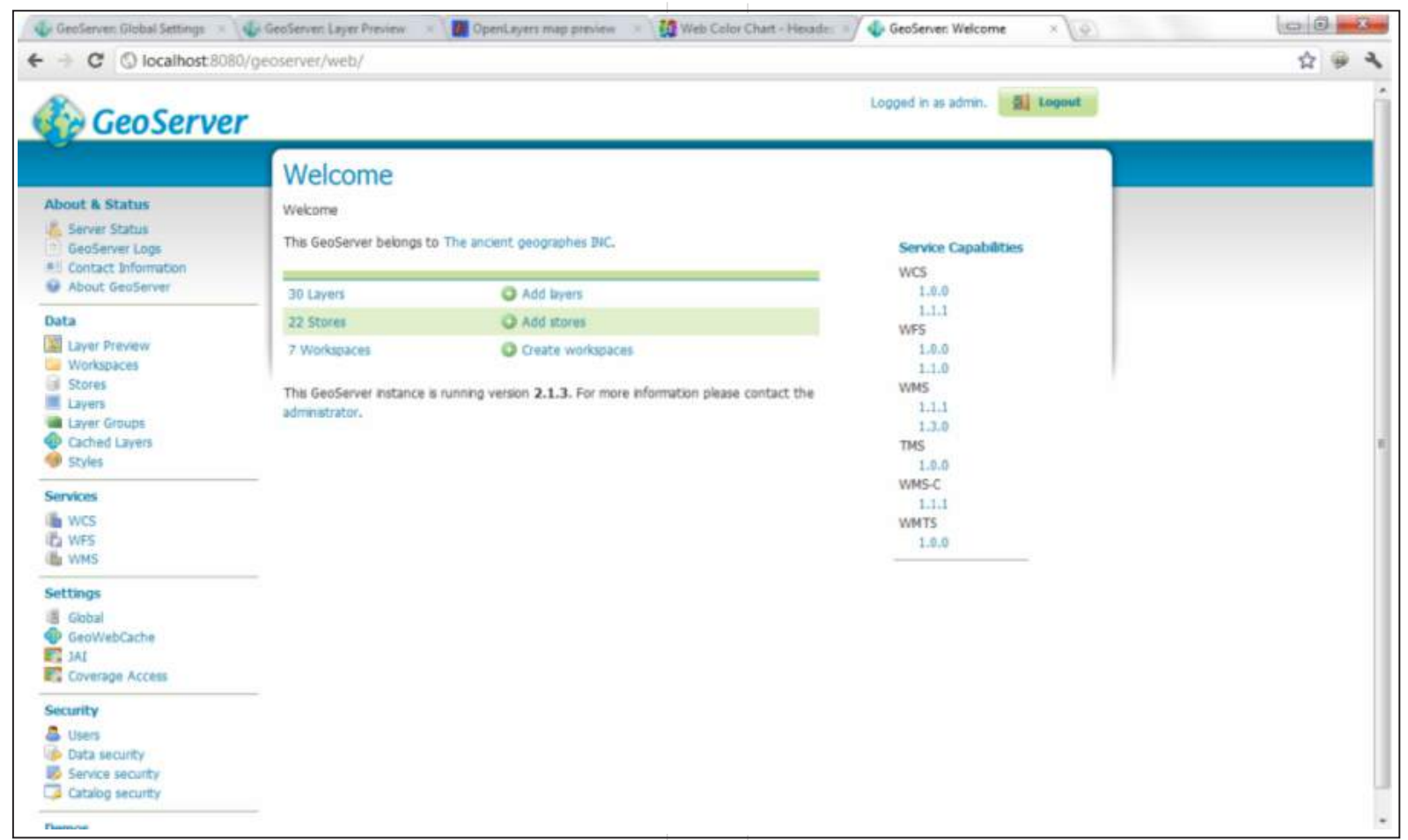

Gambar 6. Halaman awal GeoServer

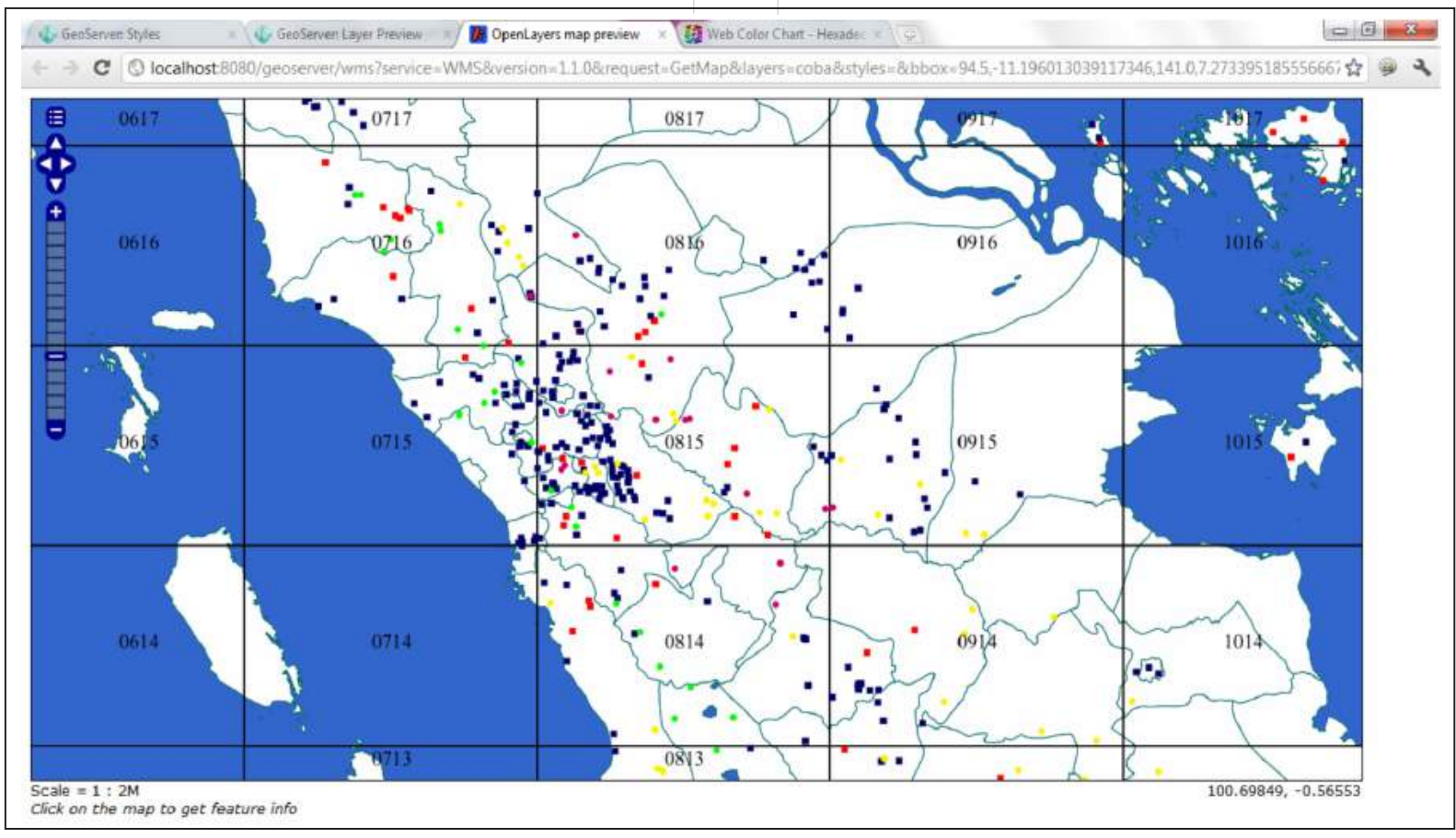

Gambar 7. Aplikasi WebGIS Metadata sumber daya mineral dan energi 


\section{MAKALAH ILMIAH}

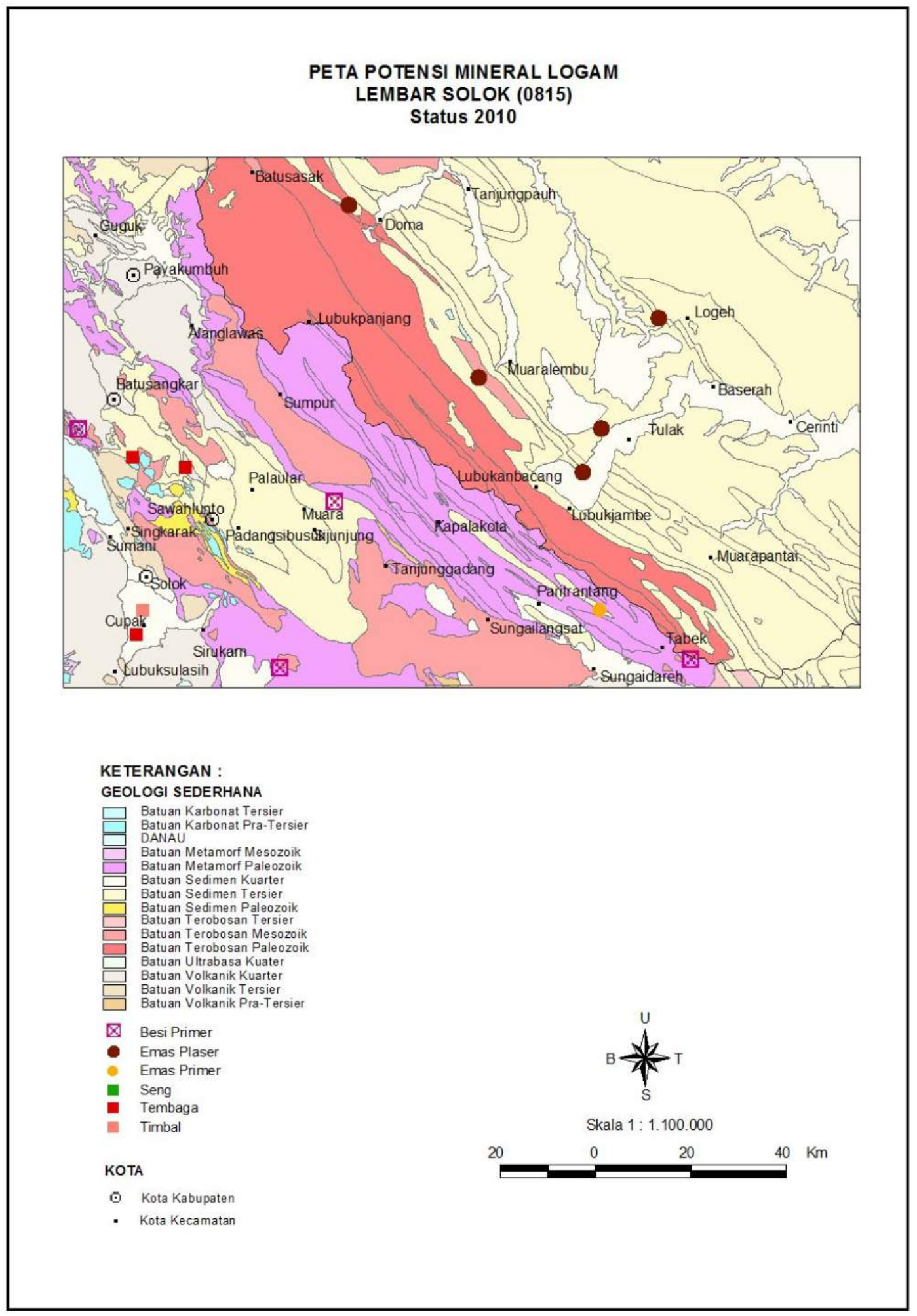

Gambar 8. Peta metadata potensi mineral logam Lembar Solok (0815) 
Tabel 2.

Tabel metadata potensi mineral logam dan geologi disederhanakan Lembar Solok (0815)

\begin{tabular}{|c|c|c|}
\hline \multicolumn{3}{|c|}{ METADATA MINERAL LOGAM } \\
\hline 1 & pemilik_data_sitasi & Pusat Sumber Daya Geologi \\
\hline 2 & judul_sitasi & $\begin{array}{l}\text { Peta Potensi Mineral Logam dan Geologi } \\
\text { Disederhanakan Lembar Solok (0815) }\end{array}$ \\
\hline 3 & bentuk_tampilan_data_sitasi & Peta \\
\hline 4 & tempat_sitasi & Bandung \\
\hline 5 & penerbit_sitasi & Pusat Sumber Daya Geologi \\
\hline 6 & pemilik_data_larger_work_identifikasi & Pusat Sumber Daya Geologi \\
\hline 7 & judul_larger_work_identifikasi & $\begin{array}{l}\text { Peta Potensi Mineral Logam dan Geologi } \\
\text { Disederhanakan Lembar Solok (0815) }\end{array}$ \\
\hline 8 & bentuk_tampilan_data_larger_work_identifikasi & Peta \\
\hline 9 & abstrak & $\begin{array}{l}\text { Geologi Lembar Solok tersusun oleh batuan } \\
\text { karbonat Tersier, batuan karbonat Pra -Tersier, } \\
\text { batuan metamorf Mesozoikum, batuan metamorf } \\
\text { Paleozoikum, batuan sedimen Kuarter, batuan } \\
\text { sedimen Tersier, batuan sedimen Paleozoikum, } \\
\text { batuan terobosan Tersier, batuan terobosan } \\
\text { mesozoikum, batuan terobosan Paleozoikum, } \\
\text { batuan ultrabasa Kuarter, batuan volkanik Kuarter, } \\
\text { batuan volkanik Tersier, dan batuan volkanik Pra- } \\
\text { Tersier. Komoditas mineral logam yang terdapat di } \\
\text { lembar ini adalah besi primer, seng, tembaga, } \\
\text { timbal, emas primer, dan emas plaser. }\end{array}$ \\
\hline 10 & status_kemajuan & Pekerjaan Telah Selesai \\
\hline 11 & bujur_barat & $100^{\circ} 30^{\prime}$ \\
\hline 12 & bujur_timur & $102^{\circ}$ \\
\hline 13 & lintang_utara & $0^{\circ}$ \\
\hline 14 & lintang_selatan & $-1^{\circ}$ \\
\hline 15 & kata_kunci_tema & $\begin{array}{l}\text { Besi primer, seng, tembaga, timbal, emas primer, } \\
\text { dan emas plaser. }\end{array}$ \\
\hline 16 & tempat_thes & $\begin{array}{l}\text { Kabupaten:Dharmasraya, Kampar, Kota Sawah } \\
\text { Lumto, Kuantan Sengingi, Sawahlunto - Sijunjung, } \\
\text { Solok, Tanah Datar. }\end{array}$ \\
\hline 17 & personil_titik_kontak & Ir. Rina Wahyuningsih \\
\hline 18 & organisasi_utama_titik_kontak & Pusat Sumber Daya Geologi \\
\hline 19 & jabatan_titik_kontak & Kepala Sub Bidang Pengembangan Informasi \\
\hline 20 & alamat_titik_kontak & Jalan Soekarno Hatta No. 444 \\
\hline 21 & kota_titik_kontak & Bandung \\
\hline 22 & propinsi_titik_kontak & Jawa Barat \\
\hline 23 & kode_pos_titik_kontak & 40254 \\
\hline 24 & negara_titik_kontak & Indonesia \\
\hline 25 & telepon_titik_kontak & 62225226270 \\
\hline 26 & faksimili_titik_kontak & 62225226270 \\
\hline 27 & email_titik_kontak & httpllpsdg.bgl.esdm.go.id \\
\hline 28 & jam_kontak_titik_kontak & $08.00 \mathrm{~s} / \mathrm{d} 16.00$ \\
\hline 29 & tgl_metadata & $12 / 04 / 2011$ \\
\hline 30 & nama_standars & FGDC-Content Standar for Geospatial Metadata \\
\hline 31 & versi & Pusat Sumber Daya Geologi \\
\hline
\end{tabular}




\section{MAKALAH ILMIAH}

\section{PETA POTENSI MINERAL BUKAN LOGAM DAN BATUAN \\ LEMBAR SOLOK (0815) \\ Status 2010}

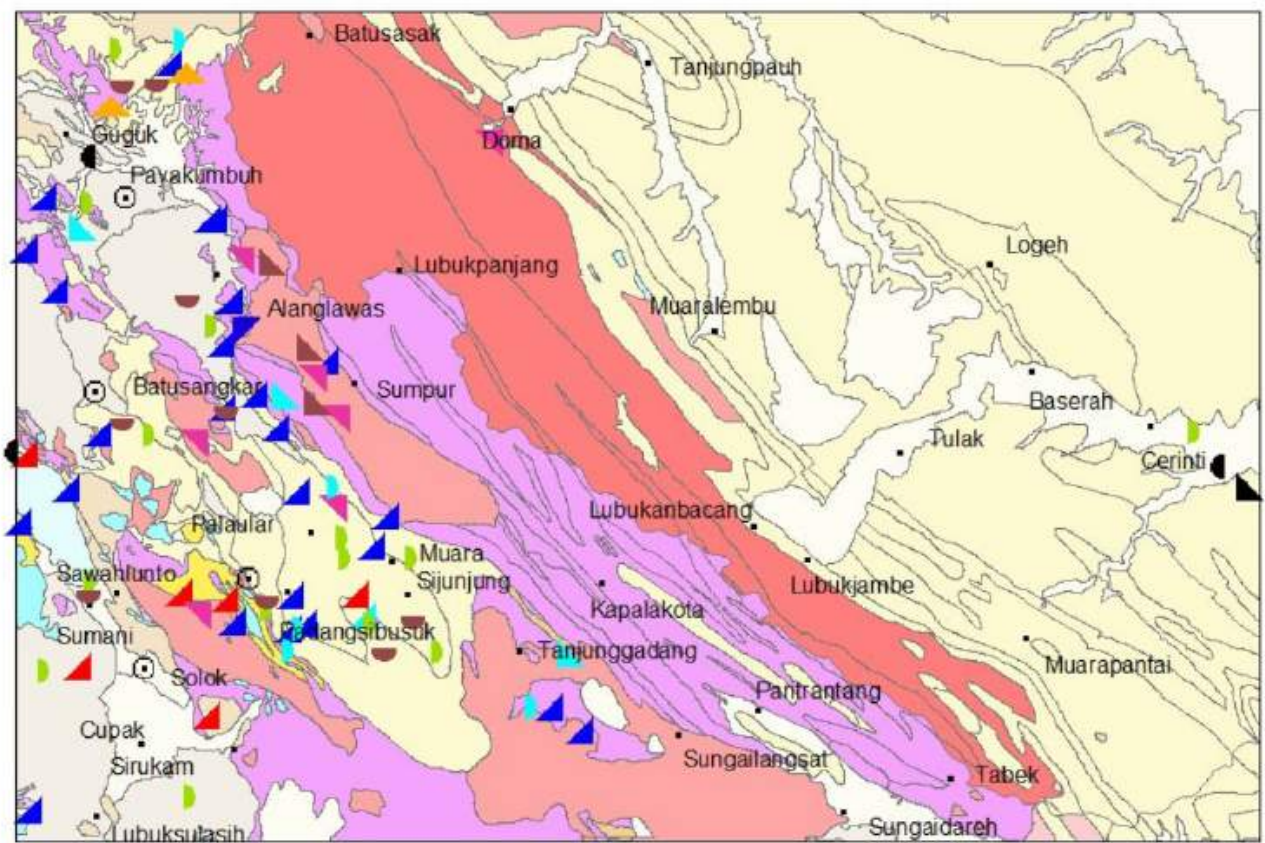

KETERANGAN :

GEOLOGI SEDERHANA

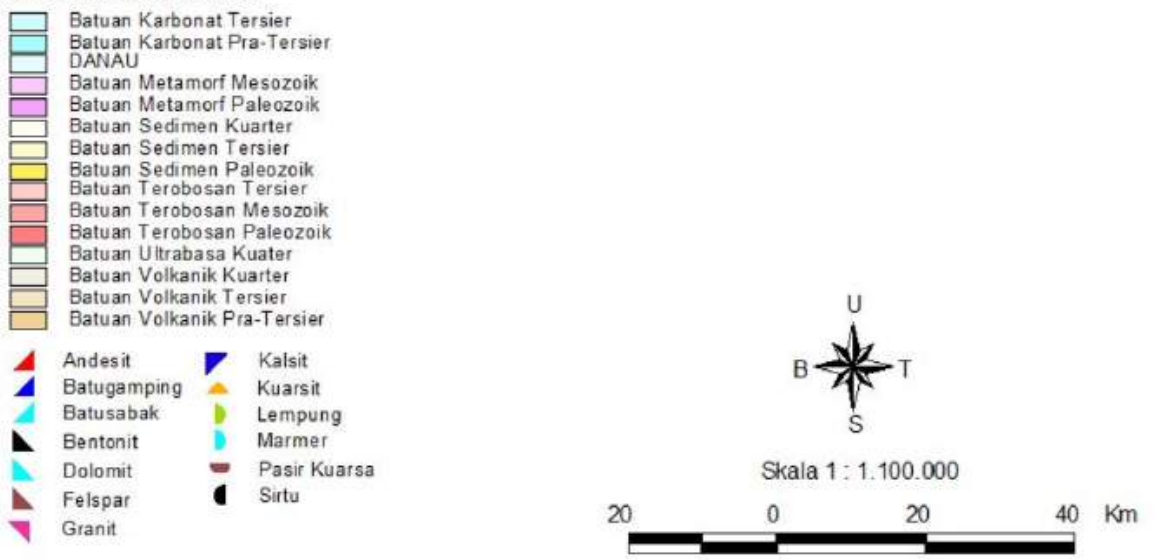

KOTA

(c) Kota Kabupaten

- Kota Kecamatan

Gambar 9. Peta metadata potensi mineral bukan logam dan batuan Lembar Solok (0815) 
Tabel 3.

Tabel metadata potensi mineral bukan logam dan batuan Lembar Solok (0815)

\begin{tabular}{|c|c|c|}
\hline \multicolumn{3}{|c|}{ METADATA MINERAL BUKAN LOGAM DAN BATUAN } \\
\hline 1 & pemilik_data_sitasi & Pusat Sumber Daya Geologi \\
\hline 2 & judul_sitasi & $\begin{array}{l}\text { Peta Potensi Mineral Bukan Logam dan Batuan serta } \\
\text { Geologi Disederhanakan Lembar Solok (0815) }\end{array}$ \\
\hline 3 & bentuk_tampilan_data_sitasi & Peta \\
\hline 4 & tempat_sitasi & Bandung \\
\hline 5 & penerbit_sitasi & Pusat Sumber Daya Geologi \\
\hline 6 & pemilik_data_larger_work_identifikasi & Pusat Sumber Daya Geologi \\
\hline 7 & judul_larger_work_identifikasi & $\begin{array}{l}\text { Peta Potensi Mineral Bukan Logam dan Batuan serta } \\
\text { Geologi Disederhanakan Lembar Solok (0815) }\end{array}$ \\
\hline 8 & bentuk_tampilan_data_larger_work_identifikasi & Peta \\
\hline 9 & abstrak & $\begin{array}{l}\text { Geologi Lembar Solok tersusun oleh batuan karbonat } \\
\text { Tersier, batuan karbonat Pra-Tersier, batuan metamorf } \\
\text { Mesozoikum, batuan metamorf Paleozoikum, batuan } \\
\text { sedimen Kuarter, batuan sedimen Tersier, batuan } \\
\text { sedimen Paleozoikum, batuan terobosan Tersier, } \\
\text { batuan terobosan mesozoikum, batuan terobosan } \\
\text { Paleozoikum, batuan ultrabasa Kuarter, batuan } \\
\text { volkanik Kuarter, batuan volkanik Tersier, dan batuan } \\
\text { volkanik Pra-Tersier. } \\
\text { Komoditas mineral bukan logam dan batuan yang } \\
\text { terdapat di lembar ini adalah andesit, batugamping, } \\
\text { batusabak, bentonit, dolomit, feldpar, granit, kalsit, } \\
\text { kuarsit, dan lempung. }\end{array}$ \\
\hline 10 & status_kemajuan & Pekerjaan Telah Selesai \\
\hline 11 & bujur_barat & $100^{\circ} 30^{\prime}$ \\
\hline 12 & bujur_timur & $102^{\circ}$ \\
\hline 13 & lintang_utara & $0^{\circ}$ \\
\hline 14 & lintang_selatan & $-1^{\circ}$ \\
\hline 15 & kata_kunci_tema & $\begin{array}{l}\text { Andesit, batugamping, batusabak, bentonit, dolomit, } \\
\text { feldpar, granit, kalsit, kuarsit, dan lempung. }\end{array}$ \\
\hline 16 & tempat_thes & $\begin{array}{l}\text { Kabupaten: Limapuluh Koto, Rambatan, Sawahlunto, } \\
\text { Sawahlunto - Sijunjung }\end{array}$ \\
\hline 17 & personil_titik_kontak & Ir. Rina Wahyuningsih \\
\hline 18 & organisasi_utama_titik_kontak & Pusat Sumber Daya Geologi \\
\hline 19 & jabatan_titik_kontak & Kepala Sub Bidang Pengembangan Informasi \\
\hline 20 & alamat_titik_kontak & Jalan Soekarno Hatta No. 444 \\
\hline 21 & kota_titik_kontak & Bandung \\
\hline 22 & propinsi_titik_kontak & Jawa Barat \\
\hline 23 & kode_pos_titik_kontak & 40254 \\
\hline 24 & negara_titik_kontak & Indonesia \\
\hline 25 & telepon_titik_kontak & 62225226270 \\
\hline 26 & faksimili_titik_kontak & 62225226270 \\
\hline 27 & email_titik_kontak & httpl|psdg.bgl.esdm.go.id \\
\hline 28 & jam_kontak_titik_kontak & $08.00 \mathrm{~s} / \mathrm{d} 16.00$ \\
\hline 29 & tgl_metadata & $12 / 04 / 2011$ \\
\hline 30 & nama_standars & FGDC-Content Standar for Geospatial Metadata \\
\hline 31 & versi & Pusat Sumber Daya Geologi \\
\hline 32 & Biaya & $\begin{array}{l}\text { Hardcopy format A3 + Tabel Potensi Kabupaten Rp. } \\
70.000 . \\
\text { Hardcopy format A0 + Tabel Potensi Propinsi Rp. } \\
\text { 350.000. }\end{array}$ \\
\hline 33 & Instruksi Pemesanan & $\begin{array}{l}\text { Mengajukan surat Permohonan data ditujukan kepada } \\
\text { Kepala Pusat Sumber Daya Geologi, untuk } \\
\text { perorangan mengisi formulir permohonan } \\
\text { data/informasi yang telah disediakan dengan } \\
\text { melampirkan fotocopy KTP }\end{array}$ \\
\hline
\end{tabular}


PETA POTENSI DAN

SEBARAN FORMASI PEMBAWA BATUBARA

LEMBAR SOLOK (0815)

Status 2010

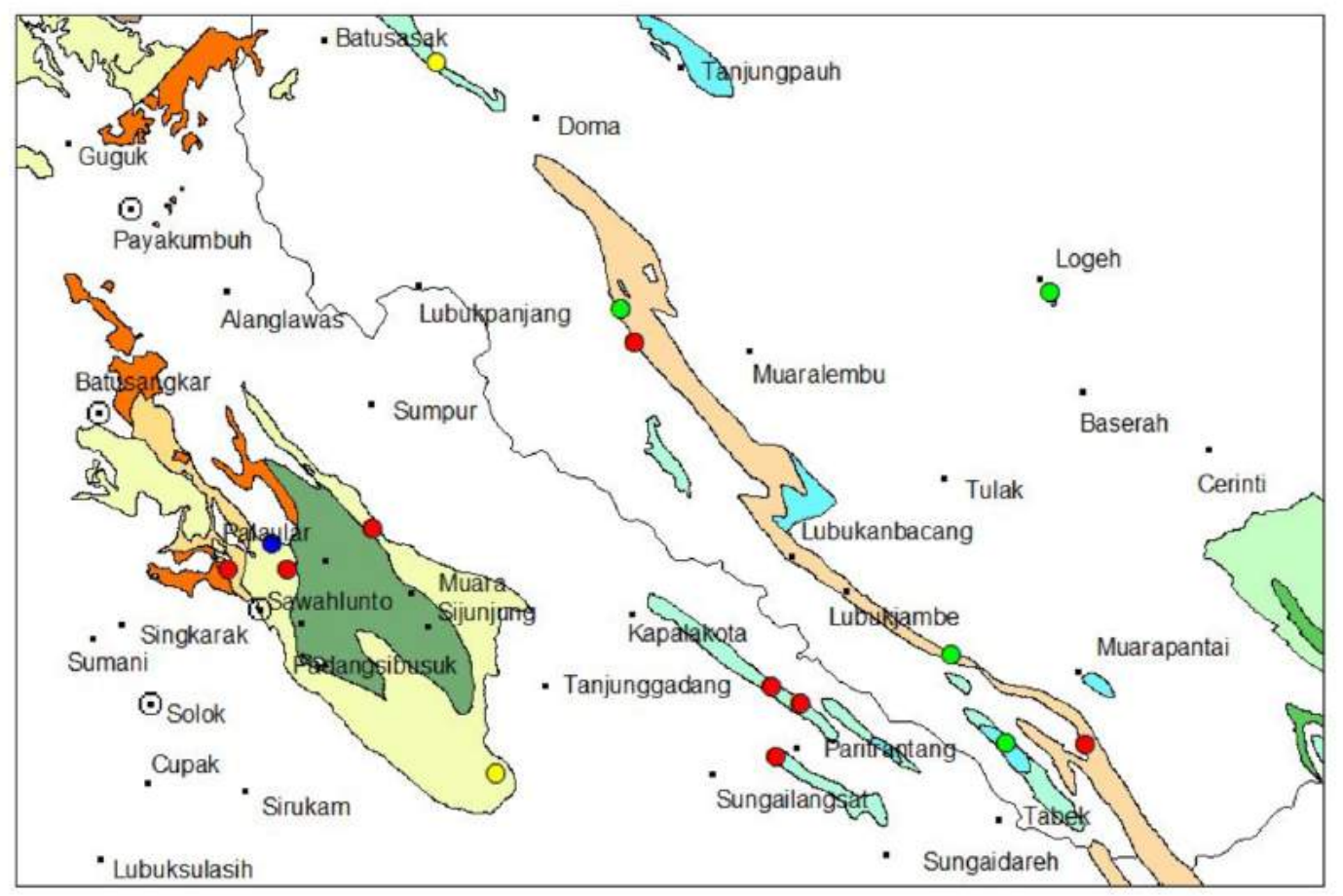

\section{KETERANGAN :}

\section{FORMASI BATUBARA}

Formasi Air Benakat

Formasi Anggota Atas Fm Ombilin

Formasi Anggota Atas Fm Telisa

Formasi Anggota Bawah Fm Ombilin

Formasi Anggota Bawah Fm Telisa

Formasi Brani

Formasi Muaraenim

Formasi Sihapas

Formasi Sinamar/Sangkarewang

Formasi Talangakar

Nilai Kalori Batubara

O Rendah ( $<5100 \mathrm{kal} / \mathrm{gr}$ )

Sedang ( $5100-6100 \mathrm{kal} / \mathrm{gr})$

Tinggi ( $6100-7100 \mathrm{kal} / \mathrm{gr})$

Sangat Tinggi ( $>7100 \mathrm{kal} / \mathrm{gr}$ )

KOTA

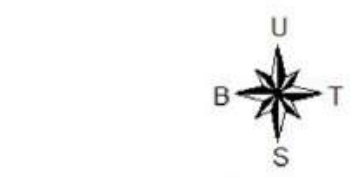

Skala $1: 1.100 .000$

20

0

20

- Kota Kabupaten

- Kota Kecamatan

Gambar 10. Peta metadata potensi potensi dan sebaran formasi pembawa batubara Lembar Solok (0815) 
Tabel 5.

Tabel metadata potensi bitumen padat Lembar Solok (0815)

\begin{tabular}{|c|c|c|}
\hline \multicolumn{3}{|c|}{ METADATA BATUBARA } \\
\hline 1 & pemilik_data_sitasi & Pusat Sumber Daya Geologi \\
\hline 2 & judul_sitasi & $\begin{array}{l}\text { Peta Potensi dan Sebaran Formasi Pembawa Batubara } \\
\text { Lembar Solok (0815) }\end{array}$ \\
\hline 3 & bentuk_tampilan_data_sitasi & Peta \\
\hline 4 & tempat_sitasi & Bandung \\
\hline 5 & penerbit_sitasi & Pusat Sumber Daya Geologi \\
\hline 6 & pemilik_data_larger_work_identifikasi & Pusat Sumber Daya Geologi \\
\hline 7 & judul_larger_work_identifikasi & $\begin{array}{l}\text { Peta Potensi dan Sebaran Formasi Pembawa Batubara } \\
\text { Lembar Solok (0815) }\end{array}$ \\
\hline 8 & bentuk_tampilan_data_larger_work_identifikasi & Peta \\
\hline 9 & abstrak & $\begin{array}{l}\text { Formasi pembawa batubara di Lembar Solok adalah } \\
\text { Formasi Telisa, Formasi Ombilin, Formasi Air Benakat, } \\
\text { Formasi Muaraenim, Formasi Talangakar, Formasi } \\
\text { Sihapas, Formasi Sinamar, dan Formasi Brani. } \\
\text { Batubara terdapat di Provinsi Riau dan Sumatra Barat } \\
\text { dengan nilai kalori rendah - sangat tinggi. }\end{array}$ \\
\hline 10 & status_kemajuan & Pekerjaan Telah Selesai \\
\hline 11 & bujur_barat & $100^{\circ} 30^{\prime}$ \\
\hline 12 & bujur_timur & $102^{\circ}$ \\
\hline 13 & lintang_utara & $0^{\circ}$ \\
\hline 14 & lintang_selatan & $-1^{\circ}$ \\
\hline 15 & kata_kunci_tema & Formasi berumur Neogen, Paleogen \\
\hline 16 & tempat_thes & - \\
\hline 17 & personil_titik_kontak & Ir. Rina Wahyuningsih \\
\hline 18 & organisasi_utama_titik_kontak & Pusat Sumber Daya Geologi \\
\hline 19 & jabatan_titik_kontak & Kepala Sub Bidang Pengembangan Informasi \\
\hline 20 & alamat_titik_kontak & Jalan Soekarno Hatta No. 444 \\
\hline 21 & kota_titik_kontak & Bandung \\
\hline 22 & propinsi_titik_kontak & Jawa Barat \\
\hline 23 & kode_pos_titik_kontak & 40254 \\
\hline 24 & negara_titik_kontak & Indonesia \\
\hline 25 & telepon_titik_kontak & 62225226270 \\
\hline 26 & faksimili_titik_kontak & 62225226270 \\
\hline 27 & email_titik_kontak & httpllpsdg.bgl.esdm.go.id \\
\hline 28 & jam_kontak_titik_kontak & $08.00 \mathrm{~s} / \mathrm{d} 16.00$ \\
\hline 29 & tgl_metadata & $12 / 04 / 2011$ \\
\hline 30 & nama_standars & FGDC-Content Standar for Geospatial Metadata \\
\hline 31 & versi & Pusat Sumber Daya Geologi \\
\hline 32 & Biaya & $\begin{array}{l}\text { Hardcopy format A3 + Tabel Potensi Kabupaten Rp. } \\
70.000 . \\
\text { Hardcopy format A0 + Tabel Potensi Propinsi Rp. } \\
350.000 \text {. } \\
\text { Hardcopy format A0 + Tabel Potensi Indonesia Rp. } \\
750.000 \text {. } \\
\text { Softcopy format A3 + Tabel Potensi Kabupaten Rp. } \\
\text { 150.000. } \\
\text { Softcopy format A0 + Tabel Potensi Propinsi Rp. } \\
500.000 \text {. } \\
\text { Softcopy format A0 + Tabel Potensi Indonesia Rp. } \\
1.250 .000 \text {. }\end{array}$ \\
\hline 33 & Instruksi Pemesanan & $\begin{array}{l}\text { Mengajukan surat Permohonan data ditujukan kepada } \\
\text { Kepala Pusat Sumber Daya Geologi, untuk perorangan } \\
\text { mengisi formulir permohonan data/informasi yang telah } \\
\text { disediakan dengan melampirkan fotocopy KTP }\end{array}$ \\
\hline
\end{tabular}




\section{MAKALAH ILMIAH}

\section{PETA LOKASI DAN POTENSI PANAS BUMI \\ LEMBAR SOLOK ( 0815 ) \\ Status 2010}

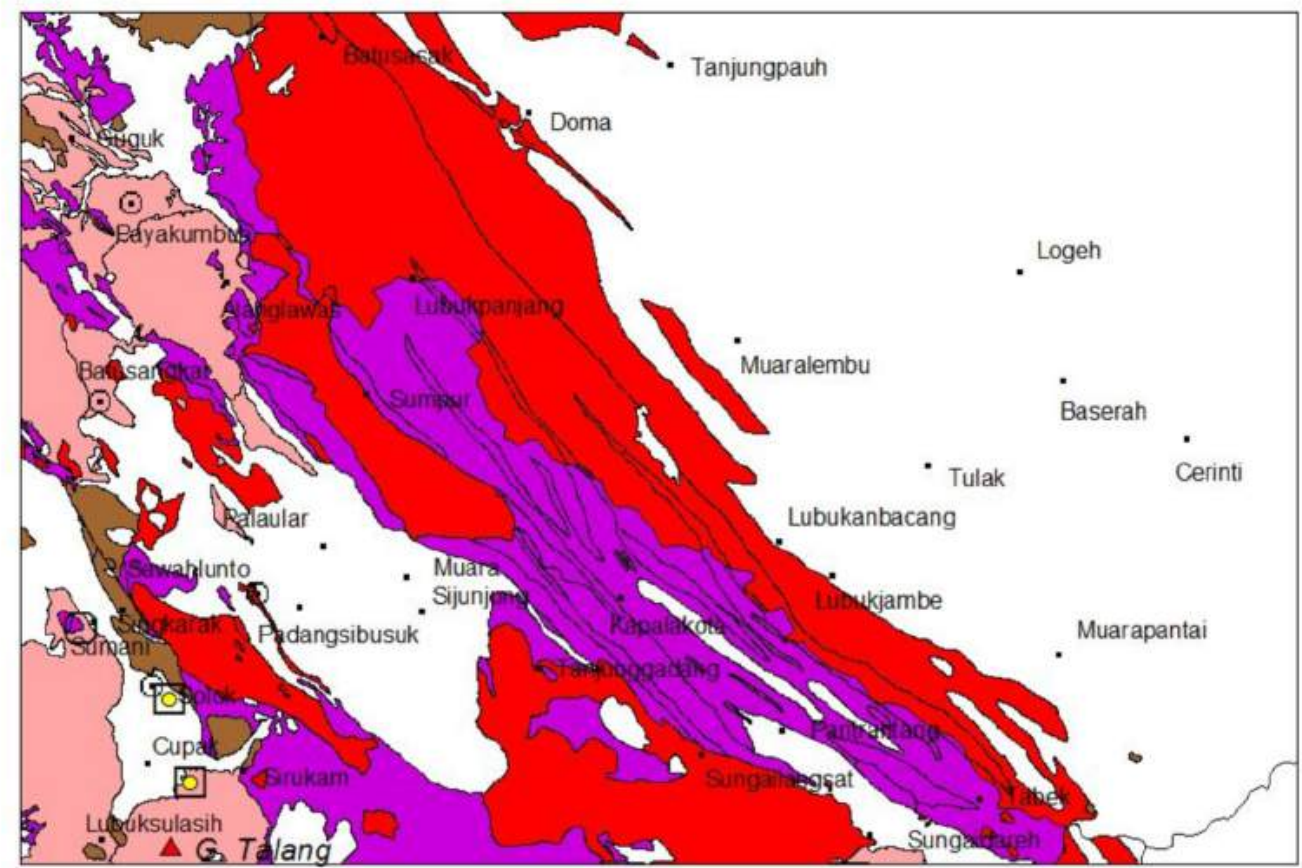

KETERANGAN :

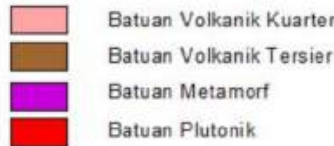

LOKASI PANAS BUM!

Berdasarkan Tahapan Penyelidikan:

0 Survei Pendahuluan Awal

$\square \quad$ Survei Rinci

Berdasarkan Temperatur, (SNI)

Sedang $\left(125^{\circ}-225^{\circ}\right)$

- Kota Kabupaten

- Kota Kecamatan

A Gunungapi

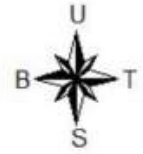

Skala $1: 1.100 .000$

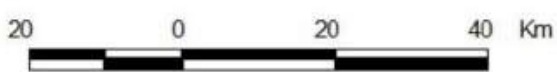

Gambar 12. Peta metadata potensi bitumen padat Lembar Solok (0815) 
Tabel 6.

Tabel metadata potensi bitumen padat Lembar Solok (0815)

\begin{tabular}{|c|c|c|}
\hline \multicolumn{3}{|c|}{ METADATA PANAS BUMI } \\
\hline 1 & pemilik_data_sitasi & Pusat Sumber Daya Geologi \\
\hline 2 & judul_sitasi & Peta Potensi Panas Bumi Lembar Solok (0815) \\
\hline 3 & bentuk_tampilan_data_sitasi & Peta \\
\hline 4 & tempat_sitasi & Bandung \\
\hline 5 & penerbit_sitasi & Pusat Sumber Daya Geologi \\
\hline 6 & pemilik_data_larger_work_identifikasi & Pusat Sumber Daya Geologi \\
\hline 7 & judul_larger_work_identifikasi & Peta Potensi Panas Bumi Lembar Solok (0815) \\
\hline 8 & bentuk_tampilan_data_larger_work_identifikasi & Peta \\
\hline 9 & abstrak & $\begin{array}{l}\text { Lokasi Panas Bumi di lembar Solok terdiri dari tiga lokasi } \\
\text { manifestasi panas bumi, yang umumnya berlokasi di sekitar } \\
\text { gunung berapi dan tidak jauh dari sistem sesar besar } \\
\text { Sumatera. Manifestasi panas bumi ini terletak di Kabupaten } \\
\text { Solok, yaitu; Sumani, Bukit Kili dan G.talang. Detil survei di } \\
\text { tiga lokasi di Lembar Solok menunjukkan adanya } \\
\text { kemungkinan sumber daya spekulatif sebesar } 25 \text { MWe dan } \\
152 \text { MWe sumber daya terduga. }\end{array}$ \\
\hline 10 & status_kemajuan & Pekerjaan Telah Selesai \\
\hline 11 & bujur_barat & $100^{\circ} 30^{\prime}$ \\
\hline 12 & bujur_timur & $102^{\circ}$ \\
\hline 13 & lintang_utara & $0^{\circ}$ \\
\hline 14 & lintang_selatan & $-1^{\circ}$ \\
\hline 15 & kata_kunci_tema & Penyelidikan Pendahuluan Awal, Penyelidikan Rinci \\
\hline 16 & tempat_thes & Kabupaten: Sumatra Barat \\
\hline 17 & personil_titik_kontak & Ir. Rina Wahyuningsih \\
\hline 18 & organisasi_utama_titik_kontak & Pusat Sumber Daya Geologi \\
\hline 19 & jabatan_titik_kontak & Kepala Sub Bidang Pengembangan Informasi \\
\hline 20 & alamat_titik_kontak & Jalan Soekarno Hatta No. 444 \\
\hline 21 & kota_titik_kontak & Bandung \\
\hline 22 & propinsi_titik_kontak & Jawa Barat \\
\hline 23 & kode_pos_titik_kontak & 40254 \\
\hline 24 & negara_titik_kontak & Indonesia \\
\hline 25 & telepon_titik_kontak & 62225226270 \\
\hline 26 & faksimili_titik_kontak & 62225226270 \\
\hline 27 & email_titik_kontak & httpllpsdg.bgl.esdm.go.id \\
\hline 28 & jam_kontak_titik_kontak & $08.00 \mathrm{~s} / \mathrm{d} 16.00$ \\
\hline 29 & tgl_metadata & $12 / 04 / 2011$ \\
\hline 30 & nama_standars & FGDC-Content Standar for Geospatial Metadata \\
\hline 31 & versi & Pusat Sumber Daya Geologi \\
\hline \multirow[t]{2}{*}{32} & \multirow[t]{2}{*}{ Biaya } & $\begin{array}{l}\text { Hardcopy format A3 + Tabel Potensi Kabupaten Rp. 70.000. } \\
\text { Hardcopy format A0 + Tabel Potensi Propinsi Rp. } 350.000 \\
\text { Hardcopy format A0 + Tabel Potensi Indonesia Rp. 750.000. } \\
\text { Softcopy format A3 + Tabel Potensi Kabupaten Rp. 150.000. } \\
\text { Softcopy format A0 + Tabel Potensi Propinsi Rp. 500.000. }\end{array}$ \\
\hline & & Softcopy format A0 + Tabel Potensi Indonesia Rp. 1.250.000. \\
\hline 33 & Instruksi Pemesanan & $\begin{array}{l}\text { Mengajukan surat Permohonan data ditujukan kepada } \\
\text { Kepala Pusat Sumber Daya Geologi, untuk perorangan } \\
\text { mengisi formulir permohonan data/informasi yang telah } \\
\text { disediakan dengan melampirkan fotocopy KTP }\end{array}$ \\
\hline
\end{tabular}




\section{HASIL DAN PEMBAHASAN}

Aplikasi WebGIS metadata sumber daya geologi ini dijalankan dengan menggunakan fasilitas internet. Pengguna dapat melakukan pencarian data dan informasi metadata dari suatu lokasi berdasarkan lembar peta rupa bumi Indonesia. Salah satu lembar peta yang akan dijadikan contoh dalam pembahasan adalah Lembar Peta Solok dengan nomor lembar peta 0815. Pada lembar peta ini terdapat 4 komoditi, yaitu mineral logam, mineral non logam, batubara, bitumen padat dan panas bumi (gambar 8 - gambar 12 serta tabel 2 - tabel 6). Gambar 7 adalah tampilan awal WebGIS metadata sumber daya geologi yang menampilkan lembar peta metadata.

\section{KESIMPULAN}

Aplikasi Sistem Informasi Geografis metadata berbasis web ini digunakan untuk mengelola metadata sumber daya mineral dan energi di Indonesia, yaitu untuk komoditi mineral logam, mineral non logam, batubara, bitumen padat, gambut dan panas bumi. Sebelum adanya aplikasi WebGIS metadata sumber daya mineral dan energi, metadata tersebut disajikan dalam bentuk SIG bersifat stand alone yang hanya dapat dijalankan pada sebuah personal computer (PC) sehingga tidak dapat diakses oleh pengguna tanpa terlebih dahulu melakukan proses instalasi aplikasi SIG tersebut. Maka dengan adanya aplikasi WebGIS metadata ini, pengguna dapat mengakses aplikasi ini dengan menggunakan fasilitas internet tanpa harus melakukan proses instalasi aplikasi.

Selain untuk menjangkau pengguna lebih luas, aplikasi ini dapat mengelola metadata sumber daya mineral dan energi, sehingga dapat lebih mudah untuk melakukan penambahan, pengeditan, penghapusan, penyajian dan pencarian data. Pengembangan aplikasi metadata ini akan terus berlanjut seiring dengan kemajuan teknologi sistim informasi yang semakin pesat.

\section{UCAPAN TERIMAKASIH}

Terima kasih kepada Kepala Bidang Informasi, Kepala Sub Bidang Pengembangan Sistem Informasi, Kepala Sub Bidang Keprospekan dan Ibu Hartati yang telah membimbing penulis selama 4 tahun ini dalam kegiatan Pemutakhiran Metadata di Pusat Sumber Daya Geologi. Terima kasih juga kepada Penny Oktaviani, ST, MT yang telah mengisi tabel metadata sumber daya mineral dan energi, Irfan Ostman, ST dan Jimmy Dharmawan, ST yang telah mengenalkan ArcGIS dan ArcMapBook juga rekan-rekan Bidang Informasi yang terlibat dalam pengerjaan tim pemutakhiran metadata.

\section{DAFTAR PUSTAKA}

National Information Standar Organization, 2004, Understanding Metadata, NISO Press, United States of America

Riyanto, 2009, Pengembangan Aplikasi Sistem Informasi Geografis, Penerbit Gava Media, Jakarta

Kristanto H., Ir, 1999, Konsep dan Perancangan Database, PenerbutAndi, Yogyakarta

Wikipedia, 2011a, Metadata, http://en.wikipedia.org/wiki/Metadata\#Definition, diakses tanggal 21 Oktober 2011

Wikipedia, 2011b, Metadata Standars, http://en.wikipedia.org/wiki/Metadata_standards \#Available_metadata_standards, diakses tanggal 21 Oktober 2011

Wikipedia, 2011c, ArcGIS, http://en.wikipedia.org/wiki/ArcGIS, diakses tanggal 21Oktober 2011

Irwan, ST, 2011, Pengantar Geodatabase, http://www.inigis.com/pengantar-geodatabase/3183, diakses tanggal 21 Oktober 2011

Garnett J., 2011, Geoserver, http://geoserver.org/display/GEOS/Welcome, diakses tanggal 21 Oktober 2011

Diterima tanggal 05 Oktober 2011

Revisi tanggal 27 September 2011 


\section{MAKALAH ILMIAH}

\section{LAMPIRAN}

LAMPIRAN A

Tabel 7.

Komoditi Sumber Daya Mineral dan Energi

\begin{tabular}{|c|c|c|c|c|c|}
\hline POTENSI & NO & KOMODITI & POTENSI & NO & KOMODITI \\
\hline \multirow{23}{*}{$\begin{array}{l}\text { MINERAL } \\
\text { LOGAM }\end{array}$} & 1 & Air Raksa & \multirow{36}{*}{$\begin{array}{l}\text { MINERAL NON } \\
\text { LOGAM }\end{array}$} & 41 & Felspar \\
\hline & 2 & Bauksit & & 42 & Fosfat \\
\hline & 3 & Besi Laterit & & 43 & Gipsum \\
\hline & 4 & Besi Primer & & 44 & Granit \\
\hline & 5 & $\begin{array}{l}\text { Besi } \\
\text { Sedimen }\end{array}$ & & 45 & Granodiorit \\
\hline & 6 & Emas alluvial & & 46 & Intan \\
\hline & 7 & Emas Primer & & 47 & Jasper \\
\hline & 8 & Kobal & & 48 & Kalsedon \\
\hline & 9 & $\begin{array}{l}\text { Kromit } \\
\text { Plaser }\end{array}$ & & 49 & Kalsit \\
\hline & 10 & $\begin{array}{l}\text { Kromit } \\
\text { Primer }\end{array}$ & & 50 & Kaolin \\
\hline & 11 & Mangan & & 51 & Kuarsit \\
\hline & 12 & Molibdenum & & 52 & Lempung \\
\hline & 13 & Monasit & & 53 & Magnesit \\
\hline & 14 & Nikel & & 54 & Marmer \\
\hline & 15 & Pasir Besi & & 55 & Obsidian \\
\hline & 16 & Perak & & 56 & Oker \\
\hline & 17 & Platina & & 57 & Oniks \\
\hline & 18 & Seng & & 58 & Opal \\
\hline & 19 & Tembaga & & 59 & Pasir zirkon \\
\hline & 20 & Timah & & 60 & Pasirkuarsa \\
\hline & 21 & Timbal & & 61 & Peridotit \\
\hline & 22 & Titan Laterit & & 62 & Perlit \\
\hline & 23 & Titan Plaser & & 63 & Pirofilit \\
\hline \multirow{17}{*}{$\begin{array}{l}\text { MINERAL NON } \\
\text { LOGAM }\end{array}$} & 24 & Ametis & & 64 & Prehnit \\
\hline & 25 & Andesit & & 65 & Rijang \\
\hline & 26 & $\begin{array}{l}\text { Ball / Bond } \\
\text { Clay }\end{array}$ & & 66 & Serpentin \\
\hline & 27 & Barit & & 67 & Sirtu \\
\hline & 28 & Basal & & 68 & Sirtu \\
\hline & 29 & Batu Hias & & 69 & Talk \\
\hline & 30 & $\begin{array}{l}\text { Batuan } \\
\text { Kalium }\end{array}$ & & 70 & Toseki \\
\hline & 31 & Batuapung & & 71 & Trakhit \\
\hline & 32 & Batugamping & & 72 & Tras \\
\hline & 33 & Batusabak & & 73 & Travertin \\
\hline & 34 & Batusabak & & 74 & Ultrabasa \\
\hline & 35 & Belerang & & 75 & Yodium \\
\hline & 36 & Bentonit & & 76 & Zeolit \\
\hline & 37 & Dasit & \multirow[t]{4}{*}{ ENERGI } & 77 & Batubara \\
\hline & 38 & Diatomea & & 78 & BitumenPadat \\
\hline & 39 & Diorit & & 79 & Gambut \\
\hline & 40 & Dolomit & & 80 & Panas Bumi \\
\hline
\end{tabular}




\section{LAMPIRAN B}

Tabel 9.

Lembar Peta Rupa Bumi Indonesia

\begin{tabular}{|c|c|c|c|c|c|c|c|}
\hline NO & LEMBAR PETA & $\begin{array}{c}\text { NOMOR } \\
\text { LEMBAR } \\
\text { PETA }\end{array}$ & PULAU & NO & LEMBAR PETA & $\begin{array}{c}\text { NOMOR } \\
\text { LEMBAR } \\
\text { PETA }\end{array}$ & PULAU \\
\hline 1 & Banda Aceh & 0421 & Sumatera & 166 & P_Sebatik & 1920 & Kalimantan \\
\hline 2 & Bagansiapiapi & 0818 & Sumatera & 167 & Palangkaraya & 1613 & Kalimantan \\
\hline 3 & Bangko (Sarolangun) & 0913 & Sumatera & 168 & Palu (Sabang) & 2016 & Kalimantan \\
\hline 4 & Baturaja & 1011 & Sumatera & 169 & Pangkalanbuun & 1513 & Kalimantan \\
\hline 5 & Bengkalis & 0917 & Sumatera & 170 & Peg.Kapuas & 1617 & Kalimantan \\
\hline 6 & Bengkulu & 0912 & Sumatera & 171 & Pontianak & 1315 & Kalimantan \\
\hline 7 & Buriai & 0712 & Sumatera & 172 & Putusibau & 1616 & Kalimantan \\
\hline 8 & Calang / Lhokkruet & 0420 & Sumatera & 173 & Ranai & 1319 & Kalimantan \\
\hline 9 & Dabo / Kotadabok & 1015 & Sumatera & 174 & Samarinda & 1915 & Kalimantan \\
\hline 10 & Dumai & 0817 & Sumatera & 175 & Sambas & 1317 & Kalimantan \\
\hline 11 & Jambi & 1014 & Sumatera & 176 & Samboja & 1914 & Kalimantan \\
\hline 12 & Ketaun & 0812 & Sumatera & 177 & Sampanahan & 1813 & Kalimantan \\
\hline 13 & Kotaagung & 1010 & Sumatera & 178 & Bontang & 1916 & Kalimantan \\
\hline 14 & Lahat & 1012 & Sumatera & 179 & Sanggau & 1416 & Kalimantan \\
\hline 15 & Lahewa & 0517 & Sumatera & 180 & Longnawan/Sawah(Kanan) & 1717 & Kalimantan \\
\hline 16 & Lahusa / Telukdalam & 0616 & Sumatera & 181 & Siluas & 1417 & Kalimantan \\
\hline 17 & Langsa & 0620 & Sumatera & 182 & Singkawang & 1316 & Kalimantan \\
\hline 18 & Lhoksemawe & 0521 & Sumatera & 183 & Sintang & 1516 & Kalimantan \\
\hline 19 & Limbungan & 1312 & Sumatera & 184 & Tanbelan & & Kalimantan \\
\hline 20 & Lubuksikaping & 0716 & Sumatera & 185 & P. Tarakan & 1919 & Kalimantan \\
\hline 21 & Manggar & 1313 & Sumatera & 186 & Tarempa & 1119 & Kalimantan \\
\hline 22 & Manna dan Enggano & 0911 & Sumatera & 187 & Telukbutun & 1320 & Kalimantan \\
\hline 23 & Mbalong & 1212 & Sumatera & 188 & Tepianbalai_Kep.Lautkecil & 1811 & Kalimantan \\
\hline 24 & Medan & 0619 & Sumatera & 189 & Terempa_Jemaja & & Kalimantan \\
\hline 25 & Menggala & 1111 & Sumatera & 190 & Tewah Kualakurun & 1614 & Kalimantan \\
\hline 26 & Muarabungo & 0914 & Sumatera & 191 & Talok & 2017 & Kalimantan \\
\hline 27 & Muarasiberut & 0714 & Sumatera & 192 & Tanjung Selor & 1918 & Kalimantan \\
\hline 28 & Muarasikabatuan & 0614 & Sumatera & 193 & P. Sebatik & 1920 & Kalimantan \\
\hline 29 & Pulau Enggano & 0910 & Sumatera & 194 & Tumbanghiram & 1615 & Kalimantan \\
\hline 30 & Padang & 0715 & Sumatera & 195 & Tumbangmanjul & 1514 & Kalimantan \\
\hline 31 & Padangsidempuan & 0717 & Sumatera & 196 & Atambua & 2406 & Nusa Tenggara \\
\hline 32 & Painan & 0814 & Sumatera & 197 & Baing & 2105 & Nusa Tenggara \\
\hline 33 & Pakanbaru & 0816 & Sumatera & 198 & Garantan & 1906 & Nusa Tenggara \\
\hline 34 & Palembang & 1013 & Sumatera & 199 & Kupang & 2305 & Nusa Tenggara \\
\hline 35 & Pangkalpinang & 1113 & Sumatera & 200 & Larantuka & 2207 & Nusa Tenggara \\
\hline 36 & Pematang Siantar & 0718 & Sumatera & 201 & Mataram & 1807 & Nusa Tenggara \\
\hline 37 & Pulau Telo & 0615 & Sumatera & 202 & P-Komodo & 2007 & Nusa Tenggara \\
\hline 38 & Rengat & 0915 & Sumatera & 203 & Ruteng & 2107 & Nusa Tenggara \\
\hline 39 & Siaksriindrapura & 0916 & Sumatera & 204 & Sumbawa Besar & 1907 & Nusa Tenggara \\
\hline
\end{tabular}




\section{LANJUTAN LAMPIRAN B}

\begin{tabular}{|c|c|c|c|c|c|c|c|}
\hline 40 & Sibigo & 0418 & Sumatera & 205 & Tjg.Laparuno & 2005 & Nusa Tenggara \\
\hline 41 & Sibolga & 0617 & Sumatera & 206 & Tk.Tofar & 1806 & Nusa Tenggara \\
\hline 42 & Sidikalang & 0618 & Sumatera & 207 & Waikabubak & 2006 & Nusa Tenggara \\
\hline 43 & Sikakap & 0713 & Sumatera & 208 & Waingapu & 2106 & Nusa Tenggara \\
\hline 44 & Simpang_Ulin & 0621 & Sumatera & 209 & Walfukar & 2307 & Nusa Tenggara \\
\hline 45 & Sinabang & 0518 & Sumatera & 210 & Balantak & 2315 & Sulawesi \\
\hline 46 & Siromtu & 0516 & Sumatera & 211 & Banggai & 2314 & Sulawesi \\
\hline 47 & Solok & 0815 & Sumatera & 212 & Batui & 2214 & Sulawesi \\
\hline 48 & Sungai_Liat & 1114 & Sumatera & 213 & Baubau & 2210 & Sulawesi \\
\hline 49 & Sungai Penuh-Ketaun & 0813 & Sumatera & 214 & Benteng & 2109 & Sulawesi \\
\hline 50 & Takengon & 0520 & Sumatera & 215 & Beo & 2520 & Sulawesi \\
\hline 51 & Ta njungredep/Kota Agung & 1010 & Sumatera & 216 & Bonerate & 2108 & Sulawesi \\
\hline 52 & Tanjungpandan & 1213 & Sumatera & 217 & Bungku & 2213 & Sulawesi \\
\hline 53 & Tanjungpinang & 1016 & Sumatera & 218 & Gorontalo & 2316 & Sulawesi \\
\hline 54 & Tanjung Uban & 1017 & Sumatera & 219 & Issimu & 2216 & Sulawesi \\
\hline 55 & Simpang Ulin & 0621 & Sumatera & 220 & Kaburuan & & Sulawesi \\
\hline 56 & Tanjungkarang & 1110 & Sumatera & 221 & Kendari & 2212 & Sulawesi \\
\hline 57 & Tapaktuan & 0519 & Sumatera & 222 & Kep_Kawio & 2420 & Sulawesi \\
\hline 58 & Tebingtinggi & 0719 & Sumatera & 223 & KepTkBesi & 2310 & Sulawesi \\
\hline 59 & Tulungselapan & 1112 & Sumatera & 224 & Kotabunan & 2416 & Sulawesi \\
\hline 60 & Anyer (1109-5) & $1109-5$ & Jawa & 225 & Larompong & 2112 & Sulawesi \\
\hline 61 & Anyer (1110-2) & $1110-2$ & Jawa & 226 & Luwuk & 2215 & Sulawesi \\
\hline 62 & Anyer(1110-3) & $1110-3$ & Jawa & 227 & Majene & 2012 & Sulawesi \\
\hline 63 & Arjawinangun (1309-1) & $1309-1$ & Jawa & 228 & Mamuju & 2013 & Sulawesi \\
\hline 64 & Balekambang (1108-6) & $1108-6$ & Jawa & 229 & Manado & 2417 & Sulawesi \\
\hline 65 & Bandung (1209-3) & $1209-3$ & Jawa & 230 & Monte & 2311 & Sulawesi \\
\hline 66 & Banjarnegara\&Pekalongan & $1408-4$ & Jawa & 231 & P.Siau & 2418 & Sulawesi \\
\hline 67 & Banyumas & $1308-3$ & Jawa & 232 & Palelelh & 2217 & Sulawesi \\
\hline 68 & Banyuwangi & $1707-4$ & Jawa & 233 & Palopo & 2113 & Sulawesi \\
\hline 69 & Besuki & $1608-3$ & Jawa & 234 & Palu & 2015 & Sulawesi \\
\hline 70 & Bjnegara\&pklongan & $1409-1$ & Jawa & 235 & Pangkajene & 2011 & Sulawesi \\
\hline 71 & Blambangan & $1707-1$ & Jawa & 236 & Parigi & 2115 & Sulawesi \\
\hline 72 & blambangan & $1707-2$ & Jawa & 237 & Pmanui & 2312 & Sulawesi \\
\hline 73 & Blitar & $1507-6$ & Jawa & 238 & Poso & 2114 & Sulawesi \\
\hline 74 & Bojonegoro & $1508-5$ & Jawa & 239 & Raha & 2211 & Sulawesi \\
\hline 75 & Cianjur & $1209-2$ & Jawa & 240 & Sabang & 2016 & Sulawesi \\
\hline 76 & Cikarang & $1109-2$ & Jawa & 241 & Sidate & 2317 & Sulawesi \\
\hline 77 & Garut & $1208-6$ & Jawa & 242 & Sinjai & 2110 & Sulawesi \\
\hline 78 & Garut\&Pameungpeuk & $1208-3$ & Jawa & 243 & Tahuna & 2419 & Sulawesi \\
\hline 79 & Indramayu & $1309-4$ & Jawa & 244 & Talok & 2017 & Sulawesi \\
\hline 80 & Jakarta\&KepSeribu & $1210-1$ & Jawa & 245 & Tinompo & 2116 & Sulawesi \\
\hline 81 & Jakarta & $1209-4$ & Jawa & 246 & Toli-toli & 2117 & Sulawesi \\
\hline
\end{tabular}




\section{LANJUTAN LAMPIRAN B}

\begin{tabular}{|c|c|c|c|c|c|c|c|}
\hline 82 & Jampang & $1208-4$ & Jawa & 247 & Ujungpandang & 2010 & Sulawesi \\
\hline 83 & Jatirogo & $1509-2$ & Jawa & 248 & Watampone & 2111 & Sulawesi \\
\hline 84 & Jember & $1607-6$ & Jawa & 249 & Ambon & 2612 & Maluku \\
\hline 85 & Kangean \& Sapudi & $1708-4$ & Jawa & 250 & Bandanaire & 2711 & Maluku \\
\hline 86 & Karangnunggal & $1308-1$ & Jawa & 251 & Banggai & 2314 & Maluku \\
\hline 87 & Karawang & $1209-5$ & Jawa & 252 & Diofa & 2414 & Maluku \\
\hline 88 & Karawang & $1210-2$ & Jawa & 253 & Galela & 2617 & Maluku \\
\hline 89 & Karimunjawa & $1410-2$ & Jawa & 254 & Geser & 2812 & Maluku \\
\hline 90 & Kebumen & $1408-1$ & Jawa & 255 & Huaki & 2508 & Maluku \\
\hline 91 & Kediri & $1508-3$ & Jawa & 256 & Kaiwatu & 2608 & Maluku \\
\hline 92 & KrmJawa & $1410-3$ & Jawa & 257 & Kep Aru Selatan & 3009 & Maluku \\
\hline 93 & Kudus & $1409-3$ & Jawa & 258 & Kep.Watubela & 2811 & Maluku \\
\hline 94 & Kudus & $1409-6$ & Jawa & 259 & Labuha & 2515 & Maluku \\
\hline 95 & Leuwi damar & $1109-3$ & Jawa & 260 & Loji & 2514 & Maluku \\
\hline 96 & Lumajang & $1607-5$ & Jawa & 261 & Masohi & 2712 & Maluku \\
\hline 97 & Madiun & $1508-2$ & Jawa & 262 & Mesa & 2709 & Maluku \\
\hline 98 & Magelang\&Semarang & $1408-5$ & Jawa & 263 & Namlea & 2512 & Maluku \\
\hline 99 & Majenang & $1308-5$ & Jawa & 264 & Nuniafi & 2613 & Maluku \\
\hline 100 & Malang & $1608-1$ & Jawa & 265 & P Babar & 2708 & Maluku \\
\hline 101 & Mgelang\&Smarang & $1409-2$ & Jawa & 266 & P Masela & 2707 & Maluku \\
\hline 102 & Mojokerto & $1508-6$ & Jawa & 267 & P Selaru & 2807 & Maluku \\
\hline 103 & Ngawi & $1508-4$ & Jawa & 268 & P Yamd ena & 2808 & Maluku \\
\hline 104 & Pacitan & $1507-4$ & Jawa & 269 & P Morotai & 2618 & Maluku \\
\hline 105 & Pamanukan & $1209-6$ & Jawa & 270 & P_Motu & 2809 & Maluku \\
\hline 106 & Pangandaran & $1308-2$ & Jawa & 271 & Pasirputih & 2517 & Maluku \\
\hline 107 & Ponorogo & $1508-1$ & Jawa & 272 & Pulau Moa & 2607 & Maluku \\
\hline 108 & Probolinggo & $1608-2$ & Jawa & 273 & Sakata & 2615 & Maluku \\
\hline 109 & Prwkerto \& Tegal & $1309-3$ & Jawa & 274 & Sesepe & 2614 & Maluku \\
\hline 110 & Purwokerto \& Tegal & $1308-6$ & Jawa & 275 & Taberfane & 3010 & Maluku \\
\hline 111 & Rembang & $1509-1$ & Jawa & 276 & Tahuna & 2419 & Maluku \\
\hline 112 & Rembang & $1509-4$ & Jawa & 277 & Ternate & 2516 & Maluku \\
\hline 113 & Salatiga & $1408-6$ & Jawa & 278 & Tg Waka & 2513 & Maluku \\
\hline 114 & Sapulu & $1708-5$ & Jawa & 279 & Tual & 2910 & Maluku \\
\hline 115 & Sapulu & $1609-1$ & Jawa & 280 & Wahai & 2713 & Maluku \\
\hline 116 & Serang & $1109-6$ & Jawa & 281 & Waigeobarat & 2715 & Maluku \\
\hline 117 & Sindangbarang & $1208-2$ & Jawa & 282 & Weda & 2616 & Maluku \\
\hline 118 & Sindangbarang & $1208-5$ & Jawa & 283 & Wetar Barat & 2408 & Maluku \\
\hline 119 & Situbondo & $1708-1$ & Jawa & 284 & Beoga & 3212 & Papua \\
\hline 120 & SRkarta\&GRTontro & $1408-3$ & Jawa & 285 & Birufu & 3310 & Papua \\
\hline 121 & Sukamade & $1607-3$ & Jawa & 286 & Bosnik & 3114 & Papua \\
\hline 122 & Surabaya & $1608-4$ & Jawa & 287 & Bufareh & 3313 & Papua \\
\hline 123 & Surakarta\&Giritontro & $1407-6$ & Jawa & 288 & Fakfak & 2913 & Papua \\
\hline
\end{tabular}




\section{LANJUTAN LAMPIRAN B}

\begin{tabular}{|c|c|c|c|c|c|c|c|}
\hline 124 & Tasikmalaya & $1308-4$ & Jawa & 289 & G_Dom & 3213 & Papua \\
\hline 125 & Tjbumi\&Pamekasan & $1609-2$ & Jawa & 290 & Gasim & 2814 & Papua \\
\hline 126 & TjgBumi\&Pamekasan & $1608-5$ & Jawa & 291 & Jayapura & 3413 & Papua \\
\hline 127 & Tuban & $1509-3$ & Jawa & 292 & Kaimana & 3012 & Papua \\
\hline 128 & Tulungagung & $1507-5$ & Jawa & 293 & Kamulu & 3307 & Papua \\
\hline 129 & Turen & $1607-4$ & Jawa & 294 & Kanoka & 2912 & Papua \\
\hline 130 & Ujungkulon & $1109-1$ & Jawa & 295 & Kep.Ayu & 2816 & Papua \\
\hline 131 & Waru\&Sumenep & $1608-6$ & Jawa & 296 & Kerom & 3412 & Papua \\
\hline 132 & waru-Sumenep & $1609-3$ & Jawa & 297 & Kloder & 3207 & Papua \\
\hline 133 & Yogyakarta & $1407-5$ & Jawa & 298 & Korim & 3115 & Papua \\
\hline 134 & Yogyakarta & $1408-2$ & Jawa & 299 & Manokwari & 3015 & Papua \\
\hline 135 & Denpasar & 1707 & Bali & 300 & Mapi & 3308 & Papua \\
\hline 136 & Mataram & 1807 & Bali & 301 & Merauke & 3407 & Papua \\
\hline 137 & Amuntai & 1713 & Kalimantan & 302 & Modowi & 3011 & Papua \\
\hline 138 & Anoname & & Kalimantan & 303 & Muting & 3408 & Papua \\
\hline 139 & Apobayang_Glemang & 1719 & Kalimantan & 304 & Nabire & 3112 & Papua \\
\hline 140 & Balikpapan & 1814 & Kalimantan & 305 & Oksibil & 3410 & Papua \\
\hline 141 & Banjarmasin & 1712 & Kalimantan & 306 & P.Misool & 2714 & Papua \\
\hline 142 & Batakan & 1711 & Kalimantan & 307 & P_Adi & 2911 & Papua \\
\hline 143 & Buntok & 1714 & Kalimantan & 308 & P_Sayang & 2716 & Papua \\
\hline 144 & P. Moratua & 2018 & Kalimantan & 309 & P_Waigeo & & Papua \\
\hline 145 & P. Karimata & 1314 & Kalimantan & 310 & Pc_Trikora & 3311 & Papua \\
\hline 146 & Kendawangan & 1413 & Kalimantan & 311 & Peg_Jayawijaya & 3411 & Papua \\
\hline 147 & Kep. Natunasel & 1318 & Kalimantan & 312 & Ransiki & 3014 & Papua \\
\hline 148 & Ketapang & 1414 & Kalimantan & 313 & Sarabin & 3309 & Papua \\
\hline 149 & Kotabaru & 1812 & Kalimantan & 314 & Sarmi & 3314 & Papua \\
\hline 150 & Kualapembuang & 1612 & Kalimantan & 315 & Sausapor & 2915 & Papua \\
\hline 151 & Longhiram_Tenggarang & 1815 & Kalimantan & 316 & Sausapor & 2915 & Papua \\
\hline 152 & Longnawan & 1717 & Kalimantan & 317 & Sawai & 3214 & Papua \\
\hline 153 & Longpahangai & 1716 & Kalimantan & 318 & Sorong & 2815 & Papua \\
\hline 154 & Lumbis & 1820 & Kalimantan & 319 & Tanahmerah & 3409 & Papua \\
\hline 155 & Malinau & 1819 & Kalimantan & 320 & Telukberau & 2813 & Papua \\
\hline 156 & Midai & & Kalimantan & 321 & Tembagapura & 3211 & Papua \\
\hline 157 & Muaraancalung & 1816 & Kalimantan & 322 & Teminabuan & 2914 & Papua \\
\hline 158 & Muaradua Tg.Puting & 1512 & Kalimantan & 323 & U_Mapi & 3208 & Papua \\
\hline 159 & Muaralasan & 1917 & Kalimantan & 324 & Wahai & 2713 & Papua \\
\hline 160 & Muaratewa & 1715 & Kalimantan & 325 & Waigeobarat & 2715 & Papua \\
\hline 161 & Muarawahau & 1817 & Kalimantan & 326 & Waisor & 3013 & Papua \\
\hline 162 & Nangaobat & 1517 & Kalimantan & 327 & Wamena & 3312 & Papua \\
\hline 163 & Nangapinoh & 1515 & Kalimantan & 328 & Waren & 3113 & Papua \\
\hline 164 & Nangataman & 1415 & Kalimantan & 329 & Yapekopra & 3111 & Papua \\
\hline 165 & Napaku(Longbia) & 1818 & Kalimantan & 330 & Yapero & 3210 & Papua \\
\hline
\end{tabular}

